\title{
Enalapril stimulates collagen biosynthesis through prolidase-dependent mechanism in cultured fibroblasts
}

\author{
Lukasz Szoka • Ewa Karna $\cdot$ Renata Pawlak Morka • \\ Jerzy A. Palka
}

Received: 2 December 2014 / Accepted: 4 March 2015 / Published online: 17 March 2015

(C) The Author(s) 2015. This article is published with open access at Springerlink.com

\begin{abstract}
The mechanism of a lower incidence of dermatological manifestations in patients treated with enalapril compared to patients treated with other ACE-inhibitors, e.g., captopril, is not known. The finding that prolidase plays an important role in collagen biosynthesis and that some angiotensin-converting enzyme inhibitors affect prolidase activity led us to evaluate its effect on collagen biosynthesis in cultured human skin fibroblasts. Since insulin-like growth factor (IGF-I) and transforming growth factor beta 1 (TGF- $\beta 1$ ) are the most potent stimulators of both collagen biosynthesis and prolidase activity, and prolidase is regulated by $\beta_{1}$ integrin signaling, the effect of enalapril and enalaprilat on IGF-IR, TGF- $\beta 1$, and $\beta_{1}$ integrin receptor expressions was evaluated. Cells were treated with milimolar concentrations ( 0.3 and $0.5 \mathrm{mM})$ of enalapril and enalaprilat for $24 \mathrm{~h}$. The activity of prolidase was determined by colorimetic assay. Collagen biosynthesis was evaluated by radiometric assay. Expression of signaling proteins was evaluated using Western blot. It was found that enalapril- and enalaprilatdependent increase in prolidase activity and expression was accompanied by parallel increase in collagen biosynthesis. The exposure of the cells to $0.5 \mathrm{mM}$ enalapril and enalaprilat contributed to increase in IGF-IR and $\alpha_{2} \beta_{1}$ integrin receptor as well as TGF- $\beta 1$ and NF- $\kappa \mathrm{B}$ p 65 expressions. Enalapriland enalaprilat-dependent increase of collagen biosynthesis in fibroblasts results from increase of prolidase activity and expression, which may undergo through activation of $\alpha_{2} \beta_{1}$ integrin and IGF-IR signaling as well as upregulation of TGF- $\beta 1$ and NF- $\kappa$ B p 65 , the inhibitor of collagen gene expression.
\end{abstract}

L. Szoka • E. Karna • R. P. Morka • J. A. Palka $(\bowtie)$

Department of Medicinal Chemistry, Medical University in

Bialystok, Mickiewicza 2 D, 15-222 Bialystok, Poland

e-mail: pal@umb.edu.pl
Keywords Enalapril · Enalaprilat · Collagen biosynthesis · Fibroblasts · Prolidase

\section{Introduction}

Enalapril, (S)-1-[N-(1-etoxycarbonyl)-3-phenylpropyl]-Lproline, a prodrug, is converted by deesterification to angiotensin-converting enzyme inhibitor (ACE-I), enalaprilat, (S)-1-[N-(1-carboxy-3-phenylpropyl)-L-alanyl]-L-proline dihydrate, commonly used to control hypertension (Ovchinnikov et al. 2009). It was the first dicarboxylatecontaining ACE inhibitor, which was developed to overcome the limitations of captopril. The sulfhydryl moiety was replaced by a carboxylate moiety, but additional modifications were required in its structure to achieve a similar potency to captopril.

It was documented that treatment of hypertensive patients with enalaprilat gives a lower incidence of dermatological manifestations than results from other ACE-I treatment - captopril (Davies et al. 1984). Structurally, enalaprilat is a dipeptide having L-proline as the C-terminal residue. Dipeptides of the x-pro type are substrates exclusively for prolidase. In contrast to captopril, enalaprilat had no inhibitory effect on porcine kidney prolidase (PKP) (King et al. 1989). This dipeptidase is present in all tissues and plays an important role in the recycling of proline from imidodipeptides (derived from degradation products of collagen) for collagen re-synthesis (Yaron and Naider 1993) and cell growth (Emmerson and Phang 1993). The efficiency of recycling of proline was found to be about $90 \%$ (Jackson et al. 1975). It is evident that an absence of prolidase severely impedes the recycling of collagen proline. Some clinical symptoms related to collagen deficit can be attributed to prolidase deficiency (Freij et al. 1984; Cabrera et al. 2004; Lupi et al. 2008). On the other hand, an increased activity of liver prolidase was found during the 
fibrotic process (Myara et al. 1987). There was a positive correlation between prolidase activity and fibrosis scores in the lung (Türkbeyler et al. 2012). It suggests that the enzyme activity (despite the collagen gene expression) may be a step-limiting factor in regulation of collagen biosynthesis (Surazynski et al. 2008a). A significant increase in serum prolidase activity was observed in patients with hypertension, which was interpreted as evidence of increased collagen degradation with a higher collagen turnover rate in hypertension tissues, contributing to left ventricular hypertrophy (Demirbag et al. 2007).

Collagen, which accounts for about one third of total body proteins, is not only essential for the maintenance of connective tissue architecture. The interaction between cells and extracellular matrix (ECM) proteins, e.g., collagen, can regulate cellular gene expression, differentiation, and growth (Bissel 1981; Carey 1991). The interaction is mediated by specific cell surface receptors of integrin family. The $\alpha_{2} \beta_{1}$ integrin is known as a main collagen receptor. Activation of this receptor by collagen ligation initiates cascade of signaling pathway including FAK, Src, Shc, Grb2, Sos, Ras, Raf and MAP kinases, ERK1, and ERK2 (Boudreau and Jones 1999). Decrease in collagen availability for integrin receptor interaction may therefore potentially alter cellular metabolism. Prolidase activity is stimulated through a signal mediated by collagen- $\beta_{1}$ integrin receptor interaction (Palka and Phang 1997, 1998). This pathway is known to be involved in phosphorylation of several intracellular proteins, including prolidase (Surazynski et al. 2001).

Another important point of collagen biosynthesis regulation is at the level of insulin-like growth factor-I receptor (IGF-IR). IGF-I is one of the potent collagen-stimulating factor in collagen-synthesizing cells (Goldstein et al. 1989). Stimulated IGF-I receptor induces interaction of several signaling proteins, such as Grb2, Src, and Shc. This interaction allows activating further cascade of signaling pathway through Sos, Ras, and Raf proteins and, subsequently, two MAP kinases-ERK ${ }_{1}$ and $\mathrm{ERK}_{2}$ (Werner and Le Roith 2000). The end point of this phenomenon is induction of some transcription factors that regulate cellular metabolism. Some of these activities are regulated through NF- $\kappa \mathrm{B}$, the known inhibitor of collagen gene expression (Kouba et al. 1999). On the other hand, transforming growth factor beta 1 (TGF- $\beta 1$ ) may take part in the stimulation of collagen biosynthesis (Surazynski et al. 2010). It was documented in studies where anti-TGF- $\beta 1$ antibody or gene silencing by si-TGF- $\beta 1$ counteracted TGF- $\beta 1$-dependent increase in collagen type I production (Jiang et al. 2012).

Considering the above mentioned factors, we studied the cellular mechanisms for the effect of enalapril-prodrug and enalaprilat-active form of the drug on collagen biosynthesis in cultured human dermal fibroblasts.

\section{Materials and methods}

Alkaline phosphatase-labeled anti-mouse IgG, anti-rabbit IgG, and anti-goat IgG antibodies, bacterial collagenase, enalapril maleate salt and enalaprilat dihydrate (dissolved in DMEM), Fast BCIP/NBT reagent, L-glycyl-proline, L-proline, monoclonal (rabbit) TGF- $\beta 1$ antibody, and monoclonal (mouse) antiIGF-IR antibody were provided by Sigma Corp., USA., as were most other chemicals and buffers used. Dulbecco's minimal essential medium (DMEM) and fetal bovine serum (FBS) used in cell culture were products of Gibco, USA. Glutamine, penicillin, and streptomycin were obtained from Quality Biologicals Inc., USA. Nitrocellulose membrane $(0.2 \mu \mathrm{m})$, sodium dodecylsulphate (SDS), polyacrylamide, molecular weight standards, and Coomassie Briliant Blue R-250 were received from Bio-Rad Laboratories, USA. $\mathrm{L}-5\left[{ }^{3} \mathrm{H}\right]$ proline $(28 \mathrm{Ci} / \mathrm{mmol})$ was purchased from Amersham, UK. Monoclonal (mouse) anti- $\beta_{1}$, polyclonal (rabbit) anti- $\alpha_{2}-$ integrin and NF- $\kappa \mathrm{B}$ p 65 antibodies, and polyclonal (goat) anti- $\beta$-actin antibody were the products of Santa Cruz Biotechnology Inc., USA. Polyclonal anti-human prolidase antibody was donated by Dr. James Phang (NCI-Frederick Cancer Research and Development Center, Frederick, MD, USA).

\section{Tissue culture}

All studies were performed on normal human skin fibroblasts (CRL-1474), which were purchased from American Type Culture Collection, Manassas, VA, USA. The cells were maintained in DMEM supplemented with $10 \%$ fetal bovine serum (FBS), $2 \mathrm{mmol} / \mathrm{l}$ glutamine, $50 \mathrm{U} / \mathrm{ml}$ penicillin, and $50 \mu \mathrm{g} / \mathrm{ml}$ streptomycin at $37{ }^{\circ} \mathrm{C}$ in a $5 \% \mathrm{CO}_{2}$ incubator. Cells were counted in hemocytometer and cultured at $1 \times 10^{5}$ cells per well in $2 \mathrm{ml}$ of growth medium in six-well plates (Costar). Cells reached confluence at day 6 , and in most cases, such cells were used for assays. Cells were used in the 8th to 14th passages.

\section{Determination of prolidase activity}

The activity of prolidase was determined according to the method of Myara et al. (1982). Protein concentration was measured by the method of Lowry et al. (1951). Enzyme activity was reported as nanomoles of proline released from synthetic substrate, during one minute per milligram of supernatant protein of cell homogenate.

\section{Collagen production}

Incorporation of radioactive precursor into proteins was measured after labeling of confluent cells in growth medium with enalapril-prodrug and enalaprilat-active form for $24 \mathrm{~h}$ with $5\left[^{3} \mathrm{H}\right]$ proline $(5 \mu \mathrm{Ci} / \mathrm{ml}, 28 \mathrm{Ci} / \mathrm{mM})$ as described previously (Oyamada et al. 1990). Incorporation of tracer into collagen 
was determined by digesting proteins with purified Clostridium histolyticum collagenase, according to the method of Peterkofsky et al. (1982). Results are shown as combined values for cell plus medium fractions.

\section{SDS-PAGE}

Slab SDS-polyacrylamide gel electrophoresis (PAGE) was used, according to the method of Laemmli (1970), by using $10 \%$ SDS-polyacrylamide gel.

Western immunoblot analysis

After SDS-PAGE, the gels were allowed to equilibrate for $5 \mathrm{~min}$ in $25 \mathrm{mmol} / \mathrm{l}$ Tris and $0.2 \mathrm{~mol} / \mathrm{l}$ glycine in $20 \%(v / v)$ methanol. The protein was transferred to $0.2-\mu \mathrm{m}$ pore-sized nitrocellulose at $100 \mathrm{~mA}$ for $1 \mathrm{~h}$ by using a LKB 2117 Multiphor II electrophoresis unit. The nitrocellulose was incubated with the following: monoclonal anti- $\beta_{1}$, polyclonal anti- $\alpha_{2}$-integrin, and NF- $\kappa \mathrm{B}$ p65 antibodies at concentration 1:1000; polyclonal antibody against $\beta$-actin at concentration 1:3000; polyclonal antibody against prolidase at concentration 1:5000; and monoclonal antibodies against IGF-IR and TGF- $\beta 1$ at concentration $1: 1000$ in $5 \%$ dried milk in TBS$\mathrm{T}$ ( $20 \mathrm{mmol} / \mathrm{l}$ Tris-HCl buffer, $\mathrm{pH} 7.4$, containing $150 \mathrm{mmol} / \mathrm{l}$ $\mathrm{NaCl}$ and $0.05 \%$ Tween 20 ) for $1 \mathrm{~h}$. In order to analyze $\beta_{1}$ integrin subunit and IGF-IR second antibody-alkaline phosphatase conjugated, anti-mouse IgG (whole molecule) was added at concentration 1:7500 in TBS-T; in order to analyze prolidase, $\alpha_{2}$ integrin subunit, TGF- $\beta 1$, and NF- $\kappa$ B p 65 second antibody alkaline phosphatase conjugated, anti-rabbit IgG (whole molecule) was added at concentration 1:5000; and, in order to analyze $\beta$-actin second antibody-alkaline phosphatase conjugated, anti-goat IgG (whole molecule) was added at concentration 1:5000 in TBS-T and incubated for $30 \mathrm{~min}$ with slow shaking. Then, nitrocellulose was washed with TBS-T $(5 \times 5 \mathrm{~min})$ and submitted to Sigma-Fast BCIP/NBT reagent. The intensity of the bands was quantified by densitometric analysis.

\section{Statistics}

In all experiments, the mean values for three independent experiments done in duplicates \pm standard deviation (SD) were calculated. The results were submitted to statistical analysis using one- way ANOVA followed by Tukey test, accepting $* P<0.05$ as significant versus control.

\section{Results}

Collagen biosynthesis and prolidase activity were measured in confluent human dermal fibroblasts, which have been treated with 0.3 and $0.5 \mathrm{mM}$ enalapril and enalaprilat (dissolved in DMEM). As can be seen in Fig. 2, 24-h incubation of confluent fibroblasts in the medium containing $10 \%$ of FBS and different concentrations of enalapril or enalaprilat contributed to increase in collagen biosynthesis (Fig. 1a) and prolidase activity (Fig. 1b) in a dose-dependent manner. At 0.3 and $0.5 \mathrm{mM}$, enalapril induced increase in collagen biosynthesis to about 114 and $134 \%$, respectively. After 24-h incubation, enalaprilat at 0.3 and $0.5 \mathrm{mM}$ contributed also to increase in collagen biosynthesis to about 138 and $159 \%$, respectively (Fig. 1a).

Prolidase activity was increased to about 126 and $132 \%$ of control at 0.3 and $0.5 \mathrm{mM}$ of enalapril, respectively. At 0.3 and $0.5 \mathrm{mM}$, enalaprilat induced prolidase activity to about 128 and $142 \%$ of control, respectively (Fig. 1b).

Increase in prolidase activity due to $24-\mathrm{h}$ treatment of fibroblasts with enalapril or enalaprilat was accompanied by increase in the expression of the enzyme as shown by Western immunoblot analysis (Fig. 2a).

The data shows that both, enalapril and enalaprilat, induced increase in collagen biosynthesis in skin fibroblasts and
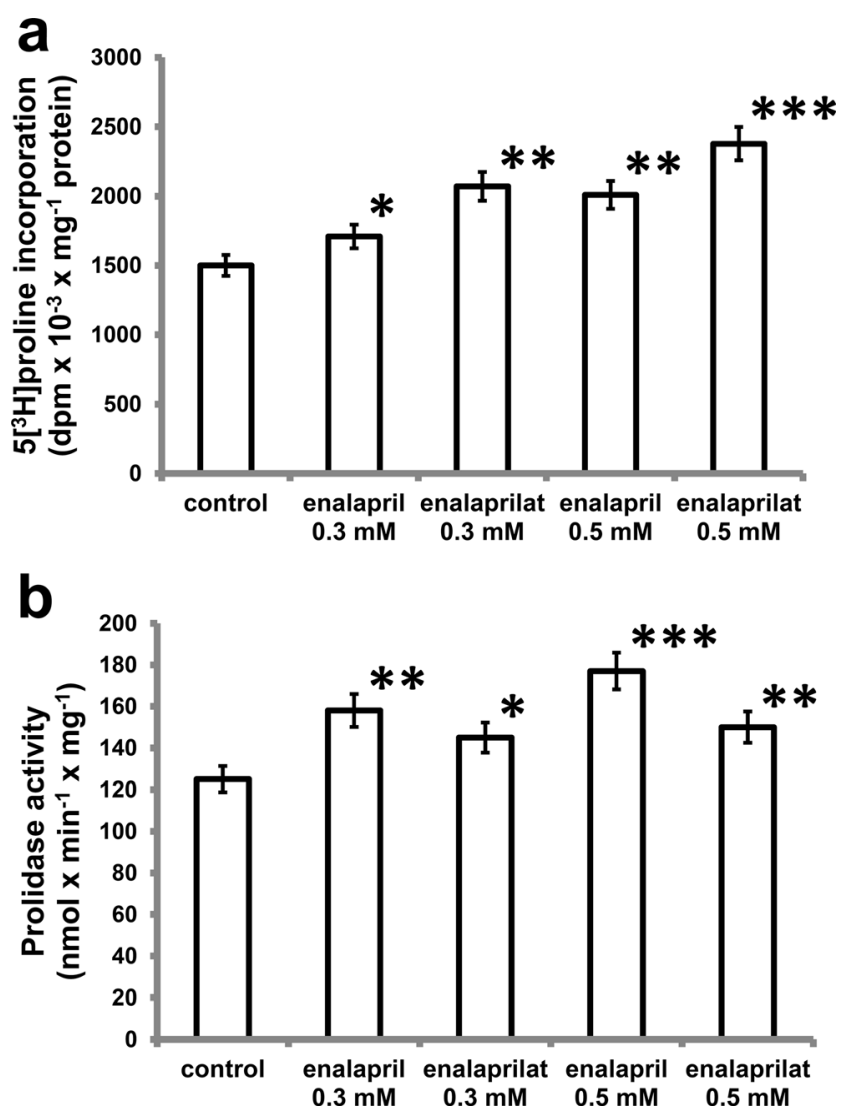

Fig. 1 Collagen biosynthesis (a) measured as $5\left[{ }^{3} \mathrm{H}\right]$ proline incorporation into proteins susceptible to the action of bacterial collagenase and prolidase activity (b) in confluent human skin fibroblasts incubated for $24 \mathrm{~h}$ in the medium containing $10 \% \mathrm{FBS}$ and different concentrations of enalapril and enalaprilat. The results present the mean values from six assays \pm SD. ${ }^{*} P<0.05 ; * * P<0.01$; *** $P<0.001$ compared with the control 


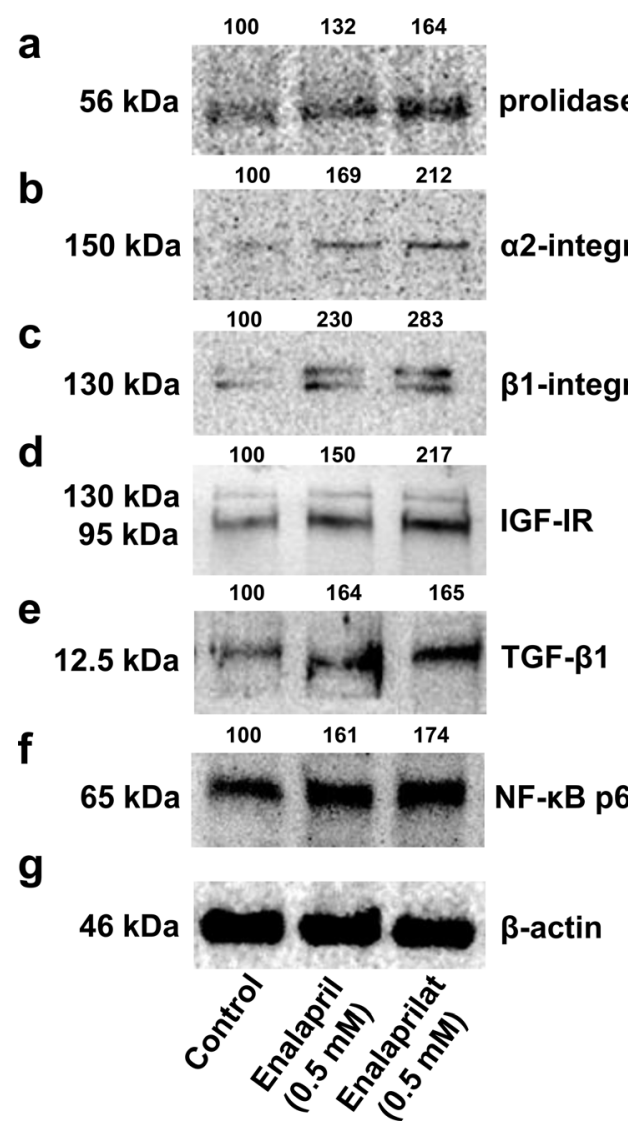

Fig. 2 Western blot analysis for prolidase (a), $\alpha_{2}$ integrin receptor (b), $\beta_{1}$ integrin receptor (c), IGF receptor (d), TGF- $\beta 1$ (e), and NF- $\mathrm{kB}$ p 65 (f) in control human skin fibroblasts (lane 1) and cultured in the medium containing $0.5 \mathrm{mM}$ of enalapril (lane 2) or $0.5 \mathrm{mM}$ of enalaprilat (lane 3). The mean values of six pooled cell homogenate extracts from six separate experiments are presented. The intensity of the bands was quantified by densitometric analysis. Densitometry was done with BioSpectrum Imaging System and presented as an arbitrary units. The same amount of supernatant protein $(20 \mu \mathrm{g})$ was run in each lane. The expression of $\beta$ actin served as a control for protein loading $(\mathbf{g})$

suggests that the increase may result from activation of prolidase activity and expression.

Collagen biosynthesis and prolidase activity were previously shown to be regulated due to the signal induced by activated $\alpha_{2} \beta_{1}$ integrin receptor (Palka and Phang 1997; Ivaska et al. 1999) as well as insulin-like growth factor-I receptor (IGF-IR) (Goldstein et al. 1989) and transforming growth factor beta (TGF beta) (McAnulty et al. 1991; Surazynski et al. 2010). Therefore, the expression of $\alpha_{2} \beta_{1}$ integrin receptor (receptor for type I collagen), IGF-IR, and TGF- $\beta 1$ were measured by Western immunoblot analysis. As can be seen in Fig. 2b, c, 24-h treatment of fibroblasts with $0.5 \mathrm{mM}$ enalapril or enalaprilat contributed to a distinct increase in the expression of $\alpha_{2}$ and $\beta_{1}$ integrin subunits, compared to the control cells (Fig. 2b, c, line 1). In addition, as shown in Fig. 2d, an increase in IGF-I receptor expression was found in enalapril- and enalaprilat-treated cells, compared to control cells. Simultaneously, we have found an increase in the expression of TGF- $\beta 1$ (Fig. 2e) and NF- $\kappa$ B p65 (Fig. 2f), the known inhibitor of collagen gene expression (Kouba et al. 1999), compared to control cells (Fig. 2e, f, line 1).

In view of this data, it seems that ability of enalapril and enalaprilat to induce collagen biosynthesis may involve increase in prolidase activity and expression, and increase in $\alpha_{2} \beta_{1}$ integrin, IGF-I receptor, TGF- $\beta 1$, and NF- $\kappa \mathrm{B}$ p 65 expressions.

\section{Discussion}

The finding that enalaprilat gives a lower incidence of dermatological manifestations than results from other ACE-I treatment, captopril (Davies et al. 1984), led us to investigate its role in collagen biosynthesis in fibroblasts - the main collagen synthesizing cells (Makela et al. 1990). It is well established that prolidase, providing proline for collagen biosynthesis, is a ratelimiting factor in regulation of this process (Karna et al. 2000, 2001; Galicka et al. 2001; Surazynski et al. 2008a). Therefore, the mechanism of prolidase activity regulation is of considerable interest. In contrast to captopril, enalaprilat had no inhibitory effect on porcine kidney prolidase (PKP) (King et al. 1989). In fact, in our previous studies (Karna et al. 2010), we found that exposure of fibroblasts to captopril contributed to a decrease in prolidase activity, and expression of $\alpha_{2} \beta_{1}$ integrin receptor and IGF-IR, suggesting underlying mechanism of captoprildependent inhibition of collagen biosynthesis. It seems that in view of dermatological manifestation that accompanies captopril therapy, the above mechanism may be of great importance.

In the present study, we found that enalapril and enalaprilat contributed to increase in prolidase activity. Their effect on the activity of other enzymes was also observed (Männistö et al. 2001). The constellation of changes induced by studied ACE inhibitors found in this study suggests an important role of prolidase in upregulation of collagen synthesis. It supports our previous studies on prolidase-dependent regulation of collagen biosynthesis (Karna et al. 2006). Several other studies suggest that prolidase-dependent regulation of collagen biosynthesis may take place at the transcriptional level. The transfection of colorectal cancer cells with prolidase vector inhibited NF-KB expression (Surazynski et al. 2008a), well-recognized inhibitor of expression of $\alpha 1$ and $\alpha 2$ subunits of type I collagen (Kouba et al. 1999; Rippe et al. 1999; Miltyk et al. 2007). Another evidence for the role of prolidase in regulation of NF-KB expression provides experiment showing that inhibition of prolidase activity by Cbz-Pro contributed to upregulation of NF-KB expression in fibroblasts (Surazynski et al. 2008a). In contrast, our data showed that enalapril- and enalaprilat-dependent increase in collagen biosynthesis is accompanied by an increase in the expression of NF- $\mathrm{kB}$ p65. Although it is accepted that enalapril inhibits NF-kB-induced inflammatory responses in several experimental "in vivo" models (Kushwaha and Jena 2012), our data on enalapril effect on NF-kB p65 expression in cultured 
fibroblasts showed contrary results. It cannot be ruled out that in the experimental conditions, enalapril upregulates coordinately expression of both NF-kB and IGF-IR (shown in our studies) since IGF-IR promoter contains NF-kB binding site (Ma et al. 2006). Such a hypothesis seems to be reasonable since recently it was found that enalapril and nifedipine differentially regulate 33 genes involved in the pathogenesis of cardiovascular diseases (Lee et al. 2013).

Enalaprilat as an angiotensin-converting enzyme inhibitor (ACE-I) has a pseudo-peptide structure with a proline residue at the position $\mathrm{P}^{\prime} 2$. This proline residue is also present in the natural substrate of ACE, angiotensin I, and it has been suggested that the preference of proline at position $\mathrm{P}^{\prime} 2$ of the peptide may reside in its rigid conformation that allows the carboxy terminus to be placed in a favorable alignment for the interaction with a positively charged amino acid of the active site of the enzyme. Important role of proline moiety at the binding process was proposed (Andújar-Sánchez et al. 2004).

There are some evidence that ACE-Is increase synthesis of collagen, one of the major constituents of the atherosclerotic cap (Claridge et al. 2004). Rhaleb et al. (2001) found that ACE-Is through indirect mechanism may contribute to regulation of collagen synthesis. We used a range of ACE inhibitors at concentrations up to $0.5 \mathrm{mM}$ because of our previous experience with captopril (Karna et al. 2010). Some studies "in vitro" were performed with higher ACE-I concentration (10 mmol/1) (Mailloux et al. 2003).

The use of ACE-Is in other animal models of atherosclerosis has shown an increase in the extracellular matrix proteins (Rabbani and Topol 1999). These phenomena were explained by the upregulation of collagen synthesis, and the presence of increased quantities of collagen in the fibrous cap (Claridge et al. 2004). Moreover, angiotensinogen, angiotensin-converting enzyme (ACE), and angiotensin II receptor are expressed in skin (Steckelings et al. 2004). It is known that ACE inhibitors might suppress skin disfunction and inflammatory response mediated through the angiotensin II pathway. Treatment with the ACE inhibitor, enalapril, counteracted UVB-induced wrinkles and skin damage (Matsuura-Hachiya et al. 2013).

Some studies have shown diverse effects of different representatives of ACE-Is on tissue collagen metabolism. Perindopril and ramipril prevented overexpression of type IV collagen mRNA in diabetic vessels (Cooper et al. 1998; Gilbert et al. 1998), while quinapril had no effect on collagen type I expression (Hernández-Presa et al. 1998).

Some studies demonstrated that captopril and enalapril improved pulmonary fibrosis in the lung tissue (Ghazi-Khansari et al. 2007). Early application of enalapril following dermal injury reduces formation of hypertrophic scars, probably because of its downregulatory effects on type III collagen production (Uzun et al. 2013). The mechanism of this process may involve TGF- $\beta 1$ participation (Tang et al. 2009; Jiang et al. 2012; Uzun et al. 2013).
In fact, our data show that enalapril and enalaprilat both increase expression of TGF- $\beta 1$. Moreover, other authors found that products of catalytic activity of prolidase, Pro and HyPro, induced increase in the amount of TGF- $\beta 1$ and receptor expression for TGF- $\beta 1$ (Surazynski et al. 2010).

Collagen is known as a ligand for $\alpha_{2} \beta_{1}$ integrin. Previously, it has been shown that $\alpha_{2} \beta_{1}$ integrin receptor is involved in signaling, which regulates collagen biosynthesis (Ivaska et al. 1999) and prolidase activity (Palka and Phang 1994, 1997). Another important point of collagen biosynthesis regulation is at the level of insulin-like growth factor-I receptor (IGF-IR). IGF-I is one of the most potent collagenstimulating factor in collagen-synthesizing cells (Goldstein et al. 1989). Therefore, we considered $\alpha_{2} \beta_{1}$ integrin and IGF-IR as a potential target in enalapril- and enalaprilatinduced increase of the above processes.

Our observations suggest that studied drugs increase collagen biosynthesis in fibroblasts primarily through increase of $\alpha_{2} \beta_{1}$ integrin receptor and IGF-I-IR expressions. Presumably, increase in prolidase activity in fibroblasts due to enalapril and enalaprilat action is a result of increase of signaling by $\alpha_{2} \beta_{1}$ integrin and IGF-IR. Both $\beta_{1}$ integrin (Palka and Phang 1997) and IGF-IR (Miltyk et al. 1998) signaling were found to play important role in prolidase activity regulation.

Although several studies on animal models have shown that enalapril and enalaprilat treatment reduces fibrosis in some tissues, it cannot correspond to reduced collagen synthesis. Upregulation of collagen synthesis may reflect interstitial remodeling leading to increase or decrease of tissue collagen content depending on the rate of collagen degradation. It was supported by some studies showing that ACE inhibitors increase type III collagen synthesis (Claridge et al. 2004).

\section{Conclusion}

The results of present study suggest that in fibroblasts, enalapril and enalaprilat may exert its effect on collagen biosynthesis through stimulation of prolidase activity and upregulation of expressions of prolidase, $\alpha_{2} \beta_{1}$ integrin, IGF-IR, TGF-beta 1 , and NF-кB p65.

Acknowledgments This work was supported by the Medical University of Białystok (Grant $N^{\mathrm{o}} 123-14881 \mathrm{~F}$ ) and conducted with the use of equipment purchased by Medical University of Białystok as part of the OP DEP 2007-2013, Priority Axis I.3, contract No. POPW.01.03.00-20008/09.

Conflict of interest The authors declare that they have no conflict of interest.

Open Access This article is distributed under the terms of the Creative Commons Attribution License which permits any use, distribution, and reproduction in any medium, provided the original author(s) and the source are credited. 


\section{References}

Andújar-Sánchez M, Cámara-Artigas A, Jara-Pérez V (2004) A calorimetric study of the binding of lisinopril, enalaprilat and captopril to angiotensin-converting enzyme. Biophys Chem 111:183-189

Bissel M (1981) How does extracellular matrix direct gene expression? J Theor Biol 99:31-68

Boudreau NJ, Jones PL (1999) Extracellular matrix and integrin signalling: the shape of things to come. Biochem J 339:481-488

Cabrera HN, Giovanna PD, Bozzini NF, Forlino A (2004) Prolidase deficiency: case reports of two Argentinian brothers. Int J Dermatol 43: 684-686

Carey DJ (1991) Control of growth and differentiation of vascular cells by extracellular matrix. Annu Rev Physiol 53:161-177

Claridge MW, Hobbs SD, Quick CR, Day NE, Bradbury AW, Wilmink AB (2004) ACE inhibitors increase type III collagen synthesis: a potential explanation for reduction in acute vascular events by ACE inhibitors. Eur J Vasc Endovasc Surg 1:67-70

Cooper ME, Cao Z, Rumble JR, Jandeleit K, Allen TJ, Gilbert RE (1998) Attenuation of diabetes-associated mesenteric vascular hypertrophy with perindopril: morphological and molecular biological studies. Metabolism 12:24-27

Davies RO, Irvin JD, Kramsch DK, Walker JF, Moncloa F (1984) Enalapril worldwide experience. Am J Med 77:23-35

Demirbag R, Yildiz A, Gur M, Yilmaz R, Elçi K, Aksoy N (2007) Serum prolidase activity in patients with hypertension and its relation with left ventricular hypertrophy. Clin Biochem 40:1020-1025

Emmerson KS, Phang JM (1993) Hydrolysis of proline dipeptides completely fulfills the proline requirement in a proline - auxotropic Chinese Hamster Ovary cell line. J Nutr 123:909-914

Freij BJ, Levy HL, Dudin G, Mutasim D, Deeb M, Der Kaloustian VM (1984) Clinical and biochemical characteristics of prolidase deficiency in siblings. Am J Med Genet 19:561-571

Galicka A, Wołczynski S, Anchim T, Surazynski A, Lesniewicz R, Palka J (2001) Defects of type I procollagen metabolism correlated with decrease of prolidase activity in a case of lethal osteogenesis imperfecta. Eur J Biochem 268:2172-2178

Ghazi-Khansari M, Mohammadi-Karakani A, Sotoudeh M, Mokhtary P, Pour-Esmaeil E, Maghsoud S (2007) Antifibrotic effect of captopril and enalapril on paraquat-induced lung fibrosis in rats. J Appl Toxicol 27:342-349

Gilbert RE, Cox A, Wu LL, Allen TJ, Hulthen UL, Jerums G, Cooper ME (1998) Expression of transforming growth factor-beta1 and type IV collagen in the renal tubulointerstitium in experimental diabetes: effects of ACE inhibition. Diabetes 47:414-422

Goldstein RH, Poliks CF, Pilch PF, Smith BD, Fine A (1989) Stimulation of collagen formation by insulin and insulin-like growth factor-I in cultures of human lung fibroblasts. Endocrinology 124:964-970

Hernández-Presa MA, Bustos C, Ortego M, Tuñón J, Ortega L, Egido J (1998) ACE inhibitor quinapril reduces the arterial expression of NF-kappaB-dependent proinflammatory factors but not of collagen I in a rabbit model of atherosclerosis. Am J Pathol 153:1825-1837

Ivaska J, Käpylä J, Pentikäinen O, Hoffrén AM, Hermonen J, Huttunen P, Johnson MS, Heino J (1999) A peptide inhibiting the collagen binding function of integrin alpha2I domain. J Biol Chem 274:3513-3521

Jackson SH, Dennis AW, Greenberg M (1975) Iminopeptiduria: a genetic defect in recycling of collagen; a method for determining prolidase in erytrocytes. CMA J 113:759-763

Jiang C, Shao L, Wang Q, Dong Y (2012) Repetitive mechanical stretching modulates transforming growth factor- $\beta$ induced collagen synthesis and apoptosis in human patellar tendon fibroblasts. Biochem Cell Biol 90:667-674

Karna E, Surazynski A, Palka J (2000) Collagen metabolism disturbances are accompanied by an increase in prolidase activity in lung carcinoma planoepitheliale. Int J Exp Pathol 81:341-347
Karna E, Miltyk W, Wołczynski S, Palka J (2001) The potential mechanism for glutamine-induced collagen biosynthesis in cultured human skin fibroblasts. Comp Biochem Physiol B 130:23-32

Karna E, Miltyk W, Palka JA (2006) Butyrate-induced collagen biosynthesis in cultured fibroblasts is independent on alpha2beta1 integrin signalling and undergoes through IGF-I receptor cascade. Mol Cell Biochem 286:147-152

Karna E, Szoka L, Palka JA (2010) Captopril-dependent inhibition of collagen biosynthesis in cultured fibroblasts. Pharmazie 65:1-4

King GF, Crossley MJ, Kuchel PW (1989) Inhibition and active-site modelling of prolidase. Eur J Biochem 180:377-384

Kouba DJ, Chung KY, Nishiyama T, Vindevoghel L, Kon A, Klement JF, Uitto J, Mauviel A (1999) Nuclear factor-kappa B mediates TNFalpha inhibitory effect on alpha 2(I) collagen (COL1A2) gene transcription in human dermal fibroblasts. J Immunol 162:4226-4234

Kushwaha S, Jena GB (2012) Enalapril reduces germ cell toxicity in streptozotocin-induced diabetic rat: investigation on possible mechanisms. Naunyn Schmiedebergs Arch Pharmacol 385:111-124

Laemmli UK (1970) Cleavage of structural proteins during the assembly of the head of bacteriophage T4. Nature 227:680-685

Lee KM, Kang HA, Ko CB, Oh EH, Park M, Lee HY, Choi HR, Yun CH, Jung WW, Oh JW, Kang HS (2013) Differential gene expression profiles in spontaneously hypertensive rats induced by administration of enalapril and nifedipine. Int J Mol Med 31:179-187

Lowry OH, Rosebrough NI, Farr AL, Randall IR (1951) Protein measurement with the Folin reagent. J Biol Chem 193:265-275

Lupi A, Tenni R, Rossi A, Cetta G, Forlino A (2008) Human prolidase and prolidase deficiency: an overview on the characterization of the enzyme involved in proline recycling and on the effects of its mutations. Amino Acids 35:739-752

Ma Y, Zhang L, Peng T, Cheng J, Taneja S, Zhang J, Delafontaine P, Du J (2006) Angiotensin II stimulates transcription of insulin-like growth factor I receptor in vascular smooth muscle cells: role of nuclear factor-kappaB. Endocrinology 147:1256-1263

Mailloux A, Deslandes B, Vaubourdolle M, Baudin B (2003) Captopril and enalaprilat decrease antioxidant defences in human endothelial cells and are unable to protect against apoptosis. Cell Biol Int 27:825-830

Makela JK, Vuorio T, Vuorio E (1990) Growth-dependent modulation of type I collagen production and mRNA levels in cultured human skin fibroblasts. Biochim Biophys Acta 1049:171-176

Matsuura-Hachiya Y, Arai KY, Ozeki R, Kikuta A, Nishiyama T (2013) Angiotensin- converting enzyme inhibitor (enalapril maleate) accelerates recovery of mouse skin from UVB-induced wrinkles. Biochem Biophys Res Commun 442:38-43

Männistö TK, Karvonen KE, Kerola TV, Ryhänen LJ (2001) Inhibitory effect of the angiotensin converting enzyme inhibitors captopril and enalapril on the conversion of procollagen to collagen. J Hypertens 10:1835-1839

McAnulty RJ, Campa JS, Cambrey AD, Laurent GJ (1991) The effect of transforming growth factor beta on rates of procollagen synthesis and degradation in vitro. Biochim Biophys Acta 1091:231-235

Miltyk W, Karna E, Wołczyński S, Pałka J (1998) Insulin-like growth factor I- dependent regulation of prolidase activity in cultured human skin fibroblasts. Mol Cell Biochem 189:177-184

Miltyk W, Karna E, Palka JA (2007) Prolidase-independent mechanism of camptothecin-induced inhibition of collagen biosynthesis in cultured human skin fibroblasts. J Biochem 141:287-292

Myara I, Charpentier C, Lemonnier A (1982) Optimal conditions for prolidase assay by proline colorimetric determination: application to imidopeptiduria. Clin Chim Acta 125:193-205

Myara I, Miech G, Fabre M, Mangeot M, Lemonnier A (1987) Changes in prolinase and prolidase activity during $\mathrm{CCl} 4$ administration inducing liver cytolysis and fibrosis in rat. Brit J Exp Pathol 68:7-13

Ovchinnikov AG, Serbul VM, Ageev FT (2009) Effects of reninangiotensin system blockers on left ventricular hypertrophy and 
biochemical markers of collagen balance in patients with hypertensive hypertrophy. Ter Arkh 81:64-71

Oyamada I, Palka J, Schalk EM, Takeda K, Peterkofsky B (1990) Scorbutic and fasted guinea pig sera contain an insulin-like growth factor I reversible inhibitor of proteoglycan and collagen synthesis in chick embryo chondrocytes and adult human skin fibroblasts. Arch Biochem Biophys 276:85-93

Palka JA, Phang JM (1994) Prolidase (PLD) activity in regulated by cell surface-extracellular matrix (ECM) interaction in normal fibroblast and MCF-7 cells. Proc Am Assoc Cancer Res 35:531

Palka JA, Phang JM (1997) Prolidase activity in fibroblasts is regulated by interaction of extracellular matrix with cell surface integrin receptors. J Cell Biochem 67:166-175

Palka JA, Phang JM (1998) Prolidase in human breast cancer MCF-7 cells. Cancer Lett 127:63-70

Peterkofsky B, Chojkier M, Bateman J (1982) Determination of collagen synthesis in tissue and cell culture system. In: Fufthmar M (ed) Immunochemistry of the extracellular matrix. CRC Press, Boca Raton, pp 19-47

Rabbani R, Topol EJ (1999) Strategies to achieve coronary arterial plaque stabilization. Cardiovasc Res 41:402-417

Rhaleb NE, Peng H, Harding P, Tayeh M, Lapointe MC, Carreto OA (2001) Effect of N-Acetyl-Seryl-Aspartyl- Proline on DNA and collagen synthesis in rat cardiac fibroblasts. Hypertension 37 : 827-832

Rippe RA, Schrum LW, Stefanovic B, Solís-Herruzo JA, Brenner DA (1999) NF-kappaB inhibits expression of the alpha1(I) collagen gene. DNA Cell Biol 18:751-761
Steckelings UM, Wollschlager T, Peters J, Henz BM, Hermes B, Artuc M (2004) Human skin: source of and target organ for angiotensin II. Exp Dermatol 13:148-154

Surazynski A, Palka J, Wolczynski S (2001) Phosphorylation of prolidase increases the enzyme activity. Mol Cell Biochem 220:95-101

Surazynski A, Miltyk W, Palka J, Phang JM (2008a) Prolidase-dependent regulation of collagen biosynthesis. Amino Acids 35:731-738

Surazynski A, Miltyk W, Prokop I, Palka J (2010) Prolidase-dependent regulation of TGF $\beta$ (corrected) and TGF $\beta$ receptor expressions in human skin fibroblasts. Eur J Pharmacol 649:115-119

Tang HT, Cheng DS, Jia YT, Ben DF, Ma B, Lv KY, Wei D, Sheng ZY, Xia ZF (2009) Angiotensin II induces type I collagen gene expression in human dermal fibroblasts through an AP-1/TGF-beta1-dependent pathway. Biochem Biophys Res Commun 385:418-423

Türkbeyler I, Demir T, Pehlivan Y, Kaplan DS, Ceribasi AO, Orkmez M, Aksoy N, Taysi S, Kisacik B, Onat AM (2012) Prolidase could act as a diagnosis and treatment mediator in lung fibrosis. Inflammation 35:1747-1752

Uzun H, Bitik O, Hekimoğlu R, Atilla P, Kaykçoğlu AU (2013) Angiotensin-converting enzyme inhibitor enalapril reduces formation of hypertrophic scars in a rabbit ear wounding model. Plast Reconstr Surg 132:361e-371e

Werner H, Le Roith D (2000) New concepts in regulation and function of the insulin-like growth factors: implication for understanding normal growth and neoplasia. Cell Mol Life Sci 57:932-942

Yaron A, Naider F (1993) Proline-dependent structural and biological properties of peptides and proteins. Crit Rev Biochem Mol Biol 28:31-81 